\title{
Motivasi menjadi Guru Bimbingan dan Konseling (Studi Fenomenologi Terhadap Fresh Graduate)
}

\author{
Andi Wahyu Irawan \\ Universitas Mulawarman \\ andiwahyuirawan@fkip.unmul.ac.id \\ Aswar \\ STKIP Muhammadiyah Baru \\ aswaralgowi@gmail.com
}

\begin{abstract}
Motivation to become a Guidance and Counseling Teacher (Phenomenology Study of Fresh Graduates): This study aims to find out the value of being a counseling guidance teacher at Senior High School in the city of Samarinda. The study used a qualitative approach with a phenomenological method. The research subjects were selected using purposive sampling in the criteria of fresh graduate and served as honorary teacher no more than one year, no more than 25 years old, and worked in a high school in the city of Samarinda. Data collected techniques were in-depth interviews and analyzed using Interpretative Phenomenological Analysis (IPA) techniques. The analysis technique sought to find meaning themes to become counseling guidance teachers. The results show three main themes, those are counseling guidance teachers interpreted as: 1) a soul calling; 2) to enjoy comfort; and 3) as a part-time job. The sub-theme of: 1) the soul calling is not profit oriented, realizing the future of students, and religious beliefs. The sub-theme of: 2) enjoy comfort that is a sense of comfort when students are helped, enjoy being parents for students, and to get life lessons. The sub-theme of: 3) part-time job is waiting to become civil servants and not easily laid off. Suggestion from this study are excepted to be a reference in helping counseling teachers in the process of valuing their work throught positive environmental conditioning to increase their productivity at work.
\end{abstract}

Key Word: Fresh, Graduate, Work, Guidance, and Teacher 


\begin{abstract}
Abstrak
Penelitian ini bertujuan untuk mengetahui makna menjadi guru bimbingan dan konseling di Sekolah Menengah Atas Kota Samarinda. Penelitian menggunakan pendekatan kualitatif dengan metode fenomenologi. Subjek penelitian dipilih menggunakan purposive sampling dengan kriteria fresh graduate dan mengabdi tidak lebih dari satu tahun, berstatus sebagai honorer, berusia tidak lebih dari 25 tahun, dan bekerja di salah satu Sekolah Menengah Atas di kota Samarinda. Teknik pengumpulan data menggunakan wawancara mendalam (in depth interview) dan dianalisis menggunakan teknik Interpretative Phenomenological Analysis (IPA). Teknik analisis tersebut berupaya menemukan tema-tema pemaknaan menjadi guru bimbingan konseling. Hasil penelitian menunjukkan tiga tema utama, yaitu guru bimbingan konseling dimaknai sebagai: 1) panggilan jiwa; 2) menikmati kenyamanan; dan 3) sebagai selingan. Subtema: 1) panggilan jiwa yaitu tidak berorientasi profit, mewujudkan masa depan siswa, dan keyakinan agama. Subtema: 2) menikmati kenyamanan yaitu rasa nyaman ketika siswa terbantu, menikmati menjadi orang tua bagi siswa, dan untuk mendapatkan pelajaran hidup. Subtema: 3) selingan yaitu menunggu menjadi ASN dan tidak mudah di PHK. Saran dari penelitian ini diharapkan menjadi rujukan dalam membantu guru bimbingan konseling dalam proses pemaknaan pekerjaannya melalui pengkondisian lingkungan yang positif untuk meningkatkan produktivitas mereka dalam bekerja.
\end{abstract}

Kata kunci: Fresh, Graduate, Pekerjaan, Bimbingan, dan Guru

\title{
A. Pendahuluan
}

Pekerjaan merupakan suatu aktivitas kehidupan yang dilakukan untuk mencapai kebutuhan. Manusia hidup untuk memenuhi kebutuhannya, sekaligus menyatakan eksistensinya. Jika seseorang bekerja karena terdorong oleh kondisi tersebut, berarti kerja merupakan bagian yang paling mendasar dari kehidupannya lantaran dilakukan hanya untuk memperoleh status sosial di masyarakat. Namun, sebagian orang terdorong untuk bekerja hanya sekedar bermain-main, bersenda gura, mengisi waktu, dan bahkan berniat buruk dalam memasuki dunia tempat kerja. Jika menengok media massa alih-alih drama sinetron di sebuah stasiun TV, maka hal ini sering kita jumpai, dan hal ini bisa saja terjadi di dunia realitas masyarakat. 
Salah satu studi kualitatif yang dilakukan oleh Abraham Maslow (1954) telah menyimpulkan bahwa kebutuhan biologis merupakan kebutuhan tingkat pertama sebelum mencapai tingkat kebutuhan lainnya. Kebutuhan ini merujuk pada pemenuhan kebutuhan untuk bertahan hidup (makan dan melanjutkan keturunan). Manusia tidak akan bisa bertahan hidup tanpa makan. Untuk memenuhi kebutuhan tersebut, manusia berupaya untuk bertahan hidup dengan bekerja dan mendapatkan penghasilan untuk makan hingga mencapai tingkat kebutuhan lainnya. Bahkan tidak jarang dilakukan dengan cara-cara yang tidak dibenarkan dalam ajaran agama, semisal mencuri, begal, dan seterusnya.

Tempat kerja modern terus berubah dan profesi baru bermunculan hingga membentuk persepsi dan cara pandang manusia dalam memaknai pekerjaan. Menjadi youtuber atau conten creator misalnya, tidak harus terikat pada aturan yang kaku, datang pagi pulang sore. Atau menjadi guru di pedalaman desa, tidak mesti mendapatkan gaji yang melimpah karena kebaikan dan keramahan orang desa sudah bisa membayar segalanya. Profesi baru bermunculan dengan pendapatan yang tidak bisa dianggap remeh. Perubahan terhadap orientasi karir tersebut, telah membuka peluang lapangan pekerjaan di berbagai sektor, termasuk yang paling potensial adalah industri kreatif.

Profesi baru yang bermunculan tidak lantas membuat sebagian besar generasi 'milineals' mengikuti trend tersebut. Beberapa diantaranya masih menginginkan profesi yang sudah lama diidam-idamkan generasi sebelumnya, menjadi ASN misalnya. Menjadi ASN (Aparatur Sipil Negara) saat ini dan atau di era millenial tidak mudah. Mesti melalui seleksi yang ketat dan bersaing dengan peserta yang lain. Dulu bahkan mereka melalui tahap pertama yakni menjadi honorer. Padahal, dari segi pendapatan, menjadi honorer kurang menjanjikan kesejahteraan, utamanya kesejahteraan secara finansial.

Tenaga pendidik atau guru tidak lepas dari menjamurnya anak muda yang ingin menjadi ASN guru. Tidak sedikit yang memilih mengabdi menjadi tenaga 
honorer terlebih dahulu. Fenomena ini tentu terbilang menuai ketimpangan, karena aturan baru pemerintah mengharuskan seluruh tenaga honorer untuk tes CAT (Computer Assisted Test) layaknya formasi umum. Hal ini tentu menjadi pertanyaan, mengapa mereka ingin menjadi tenaga honorer padahal dari sisi pendapatannya cukup rendah. Jika mereka mau, masih banyak pekerjaan lain yang bisa dilakukan, semisal bekerja diperusahaan swasta dan atau berwirausaha.

Aktivitas kerja yang dilakukan akan membentuk pengalaman. Pengalaman kerja membentuk makna kerja pada setiap individu (Harpaz, 2002). Morin (2004) menambahkan bahwa makna kerja tidak hanya sebagai upaya memenuhi kebutuhan dasar dari segi ekonomi, tetapi kebutuhan sosial dan aktualisasi diri. Max Weber dalam penelitiannya mengenai pekerjaan, secara rasional dan argumentatif telah berhasil menghubungkan kehidupan beragama terhadap etika dan etos kerja. Hal tersebut tercermin dari bukunya tang berjudul The Protestant Ethic and the Spirit of Capitalism (Weber, 1987). Dalam bukunya, Weber meyakini bahwa agama protestan di Eropa Barat telah berperan besar dalam mendorong kebutuhan berprestasi ummat manusia, hingga akhirnya memunculkan paham kapitalisme. Etika kerja tersebut disebut sebagai etika protestan yang di ajarkan oleh John Calvin. Ajaran Calvin menganjurkan agar setiap manusia melakukan sesuatu yang terbaik dan berusaha agar bisa berprestasi (Weber, 2006). Ajaran tersebut berimplikasi terhadap sikap kerja keras para penganutnya. Menurut Weber, tujuan mereka bekerja keras hanya untuk mencari kekayaan, dan juga untuk mempersiapkan diri agar bisa masuk surga. Pada intinya, etika protestan mengajarkan penganutnya untuk bekerja keras dan bersungguh-sungguh tanpa berorientasi mendapatkan imbalan materil (Nadjib, 2013).

Penelitian yang dilakukan oleh Puspita (2012) mengenai makna dalam bekerja, dengan mengambil sampel dari para perawat rumah sakit swasta di kota Surabaya, menyimpulkan bahwa para perawat memaknai pekerjaannya sebagai bagian dari panggilan jiwa karena rekan kerja memberikan dukungan sosial 
sehingga dalam bekerja, mereka merasa tidak terbebani dan memiliki semangat dalam bekerja. Penelitian dengan topik serupa dilakukan oleh Rusdiana \& Affandi (2013). Mereka meneliti mengenai makna kerja bagi buruh petik lombok di Pare. Penelitian tersebut menyimpulkan bahwa para petani memaknai pekerjaannya sebagai bagian dari pengisi waktu luang, menambah penghasilan keluarga, sebagai adaptif dengan lingkungan sosial, keterpaksaan, sumber penghasilan utama demi kelangsungan keluarga, usaha mengumpulkan modal, upaya penunjukkan eksistensi diri. Penelitian lain yang dilakukan oleh Anshori \& Yuwono (2012) tentang makna kerja "abdi dalem" keraton Yogyakarta, menyimpulkan bahwa 1) Bekerja merupakan kegiatan yang bertujuan mencari ketenangan, ketentraman dan kebahagiaan, 2) Bekerja dengan prinsip nyawiji, greget, sengguh, lan ora mingkuh, 3) Nguri-uri kabudayan, 4) Prinsip sugih tanpa banda, 5) Ngalap berkah, 6) Bekerja dengan pemahaman sangkan paraning dumadi, 7) golong gilig, manunggaling kawula lan gusti, 8) Bekerja merupakan suatu kegiatan untuk srawung dan ngluru prepat, 9) Hamemayu hayuning Bawana, hamemangun karinak tiyasing sesama, 10) Bekerja dengan penuh mawas diri.

Tiga penelitian di atas menunjukkan beberapa perbedaan dalam memaknai pekerjaan. Perawat yang bekerja di rumah sakit, berbeda dalam memaknai pekerjaan jika dibandingkan dengan petani lombok dan "abdi dalem" di keratin Yogyakarta. Hal ini menunjukkan bahwa setiap orang memiliki pandangan dan persepsi masing-masing terhadap pekerjaannya, tergantung dengan pengalaman yang mereka miliki.

Makna pekerjaan sebagai guru diteliti oleh Tanudjaja (2013) melalui studi kuantitatif. Penelitiannya mengkaji mengenai hubungan antara konflik keluargakerja, makna kerja sebagai panggilan dan persepsi terhadap dukungan organisasional dengan keterikatan kerja pada guru. Penelitian tersebut menyimpulkan bahwa konflik keluarga-kerja berperan sebagai tuntutan kerja yang memunculkan stressor bagi guru, namun ada persepsi terhadap dukungan 
organisasional dan makna kerja sebagai panggilan yang mengurangi stressor dan meningkatkan keterikatan kerja. Hal ini menunjukkan bahwa meskipun terjadi konflik di keluarga maupun di pekerjaan, tetapi guru berusaha menguragi stressnya dengan mendapatkan dukungan dari teman sejawat maupun memaknai pekerjaannya sebagai suatu panggilan jiwa.

Makna kerja merupakan sekumpulan nilai-nilai, keyakinan-keyakinan, sikap dan harapan yang dimiliki seseorang dalam hubungan dengan kerja. Pemaknaan akan arti kerja bagi seseorang akan berdampak pada semangat kerja orang tersebut. Semangat kerja dibentuk dari dasar pemahaman dan spiritual individu, yang pada akhirnya akan memberikan dorongan motivasi yang kuat dalam dirinya untuk bekerja dengan maksimal (Rosso : 2010).

Fenomena yang terjadi di kota Samarinda adalah kurang terserapnya alumni bimbingan konseling di sekolah. Salah satu perguruan tinggi negeri di Samarinda yang memproduksi dan menyuplai guru bimbingan dan konseling, setiap tahunnya menerima 80 (delapan puluh) mahasiswa baru. Namun, kenyataannya hanya sedikit alumni yang bekerja sebagai guru bimbingan konseling. Mahasiswa angkatan 2012 saja, dari delapan puluh alumni, hanya 2 (dua) orang yang menjadi guru bimbingan konseling. Lantas, apa yang menyebabkan sebagian kecil alumni bimbingan konseling memilih jalan karir untuk menjadi guru dan bagaimana mereka memaknai pekerjaannya sebagai guru bimbingan konseling. Penelitian ini akan menelusuri pemaknaan kerja guru bimbingan konseling di kota Samarinda.

\section{METODE}

Penelitian ini menggunakan metode kualitatif pendekatan fenomenologi empiris untuk mengetahui makna menjadi guru bimbingan konseling bagi fresh graduate di kota Samarinda. Pendekatan ini sejatinya memfokus pada pengalaman-pengalaman yang dialami, yang dirasakan dan dipahami secara nyata oleh subjek terteliti lapangan (Mappiare-AT, 2013). Menurut Cresswell 
pendekatan fenomenologis itu sendiri merupakan upaya peneliti untuk membuat gambaran kompleks, mendalami kata-kata, melakukan studi pada situasi yang alami, dan membuat laporan rinci dari pandangan subyek penelitian (1998). Pada intinya, pendekatan fenomenologi empiris digunakan untuk mengetahui pemaknaan individu terhadap pengalamannya sendiri dalam kaitan peristiwa hidup yang telah dilalui dan atau dialaminya.

Subjek penelitian ini berjumlah 4 (empat) orang yang ditentukan dengan cara purposive sampling. Kriteria subjek penelitian adalah guru bimbingan konseling yang tergolong fresh graduate dan mengabdi tidak lebih dari satu tahun, berstatus sebagai honorer, berusia tidak lebih dari 25 tahun, dan bekerja di salah satu sekolah negeri di Kota Samarinda. Para partisipan tersebut disamarkan namanya, yaitu subjek A, B, C, dan D. Empat orang subjek penelitian tersebut akan menjadi data primer atau data utama dalam penelitian ini. Adapun data sekunder yaitu perwakilan setiap siswa yang pernah dilayani oleh guru bimbingan konseling tersebut dan dokumen terkait yang bisa menguatkan data penelitian.

Teknik pengumpulan data yang digunakan adalah wawancara mendalam dan observasi. Wawancara diatur sedemikian rupa agar berjalan secara natural dan apa adanya. Peneliti membangun hubungan emosional yang kuat agar data yang didapatkan bisa mendalam. Secara garis besar pertanyaan wawancara berkisar tentang alasan menjadi guru bimbingan dan konseling, apa makna menjadi guru bimbingan dan konseling, apa yang membuat mereka bertahan menjadi guru bimbingan dan konseling, dan bagaimana pandangannya tentang profesi lainnya yang lebih menggiurkan. Wawancara dilakukan selama 3 (tiga) kali kepada setiap subjek penelitian untuk menguji konsistensi data yang diungkapkan.

Observasi dilakukan oleh peneliti untuk mengamati sikap dan perilaku yang dilakukan oleh subjek penelitian. Observasi dilakukan ketika peneliti berkunjung dan berbincang langsung dengan guru bimbingan konseling, serta melihat dan mengamati secara langsung kinerja yang dilakukan oleh guru bimbingan 
konseling. Data-data dari observasi dibandingkan dengan wawancara untuk menguji kesesuaian diantara keduanya.

Analisis data menggunakan interpretative phenomenological analysis (IPA) dengan langkah-langkah dari Smith \& Osborn (2009), yaitu: mentranskrip seluruh data hasil wawancara menjadi verbatim, peneliti melakukan pengkodean dengan cara memberikan komentar pada masing-masing transkrip, komentar-komentar pada transkrip dibaca ulang untuk membuat label konseptual, kemudian label dikelompokkan berdasarkan kesamaan makna dan diberikan nama subtema. Subtema kemudian dianalisis untuk dikelompokkan berdasarkan kedekatan makna dan diberikan nama tema utama. Proses analisis data hingga menemukan tema-tema merupakan upaya untuk sampai pada kesimpulan penelitian. Beberapa data asli (ekstrak) ditulis dalam laporan penelitian untuk menjaga transparansi penelitian. Ekstraksi data tersebut disebut sebagai grounding in example (Elliot dkk., 1999).

\section{B. Pembahasan}

Penelitian ini bertujuan untuk menemukan makna kerja menjadi guru bimbingan dan konseling. Data-data yang didapatkan pada saat wawancara dan observasi, dikategorikan berdasarkan tema utama sesuai dengan tujuan penelitian. Tema utama dikategorikan menjadi tiga, yaitu menjadi guru sebagai panggilan jiwa, menikmati kenyamanan, dan sebagai selingan. Adapun grand theory yang dipakai dalam membahas hasil penelitian ini adalah pendekatan yang digagas oleh Donald Super dengan teori vocational self concept-nya yang telah pupoler sebagai salah satu teori besar dalam bimbingan karir atau perkembangan karir. Vocational self-concept berkembang melalui pertumbuhan fisik dan mental, observasi kehidupan bekerja, mengidentifikasi orang dewasa yang bekerja, lingkungan umum, dan pengalaman pada umumnya (Didi Tarsidi, 2007: 11). Selain itu, teori perkembangan karir yang dipakai adalah pendekatan Holland dengan model personal style-nya yang terkenal dengan akronim RIASEK (realistic, investigative, 
artistic, social, entrepising, dan conventional). Di satu sisi, konsep Max Weber paling sering digunakan dalam membahas hasil penelitian ini, utamanya keterhubungan religisiutas seseorang dengan etos kerja yang dimilikinya.

\section{Motivasi dan Makna Profesi Guru BK sebagai Jalur Karir}

\section{a. Sebagai Panggilan Jiwa dan Tidak cenderung Berorientasi Profit}

Dari hasil wawancara didapatkan: "Sejauh ini gak pernah menyesal aku mengambil jurusan BK, justru dari jurusan ini aku dapat lebih mengenal diriku, meskipun gajinya tidak seberapa, cuman 1,1 juta."Subjek A berpendapat bahwa meskipun gajinya tidak sesuai yang dia harapkan, tapi dengan mendapatkan pemahaman terhadap dirinya, ia sudah bisa bersyukur, mencirikan kepribadian seorang muslim, apalagi dengan usianya yang masih sangat muda. Hal ini semakna dengan hasi penelitian Jati, W. R. (2018) berkerangka teori Max Weber, menyatakan bahwa etos kerja pada dasarnya terdapat di berbagai ajaran agama, hanya saja disesuaikan dengan konteks sosio-kultural masyarakatnya.

Kemudian subjek B berpendapat; "Kalau bicara profit mungkin saya sudah dari dulu cari tempat lain yang jauh lebih banyak gajinya mas. Ditempat saya gajinya mepet mas, mungkin cuma cukup untuk transport." Subjek B membuat statement bahwa dirinya tetap konsisten untuk menjadi guru bimbingan konseling meskipun dengan gaji yang hanya cukup untuk biaya transport. Baginya, rejeki itu sudah diatur oleh Allah, persoalan gaji itu cuman nominal saja. Segayut dengannya, Luth (2001) menyatakan bahwa nilai-nilai yang mendominasi dalam etos kerja agama Islam adalah nilai-nilai ikhlas, cinta, tawakkal dan istikamah.

Ketika subjek C ditanya mengenai kenapa tidak menjadi pegawai swasta saja karena gajinya lebih banyak, ia kemudian menjawab; "Kenapa saya tidak jadi pegawai swasta. Bukan minat disitu mas. Minatnya di dunia pendidikan. Mengamalkan ilmu. InsyaAllah walaupun belum bisa amal materi. Amal ilmu bisa manfaat hehe..." Subjek C tampak menjadikan pekerjaannya sebagai bagian dari investasi amal jariah yang berharap dapat diperoleh hasilnya di akhirat, alih-alih 
berniat kerja untuk ibadah. Pada dasarnya memang dogma ajaran Islam demikian, yakni menganjurkan pemeluknya memanifestasikan sikap tauhid sebagai bekerja adalah ibadah (Jati, W. R., 2018).

\section{b. Mewujudkan Masa Depan Siswa}

Hasil wawancara didapatkan: "Bagi saya mewujudkan masa depan siswa adalah kerja yang luar biasa. Sampai saat ini saya masih sering komunikasi dengan siswa yang sudah selesai. Rasanya itu seperti bonus, rasa terpanggil untuk melakukan yang lebih baik untuk siswa semakin terpacu." Subjek D beranggapan bahwa kerjanya menjadi guru bimbingan dan konseling merupakan upayanya untuk mewujudkan masa depan siswa. Menurutnya, ini merupakan panggilan jiwa yang luar biasa. Ia terus berusaha memacu dirinya untuk memberikan pelayanan yang lebih baik untuk siswa. Dalam Islam hal ini tercermin dari pengamalan pesan Nabi shallallahu 'alaihi wasallam yang menyebutkan bahwa "sebaik-baik manusia adalah yang paling bermanfaat untuk orang sekitarnya." Hal ini mengalamatkan bahwa etos kerja seorang muslim adalah tercermin dari bagaimana cara mereka memahami, menghayati dan mengamalkan nilai-nilai al-Qur'an dan sunah dalam bekerja (Irham, M., 2012).

\section{c. Keyakinan Agama}

Dari hasil wawancara didapatkan: "Aku bekerja sebagai guru bimbingan konseling karena aku meyakini bahwa apa yang aku lakukan ini menjadi amal jariyah dikemudian hari. Semua yang kulakukan ini aku niatkan karena Allah. Aku jadikan ini sebagai amal ibadahku." Subjek A beranggapan bahwa apa yang dilakukannya itu merupakan amal jariyah, setiap usaha yang dia lakukan diniatkan karena Allah. Statement tersebut merupakan keyakinan subjek E terhadap ajaran agamanya. Baginya, kerja menjadi guru bimbingan konseling merupakan panggilan jiwa. Hal tersebut sejatinya merupakan kulmunasi dari pembentukan etos kerja Islami yang terpancar dari sistem keimanan atau akidah Islami berkenaan dengan 
kerja yang bertolak dari ajaran wahyu (al-Qur'an dan hadis) bekerja sama dengan akal (Thaib, E. J., 2014).

Dari seluruh deskripsi konsep selingan pada fresh graduate guru bimbingan dan konseling di atas, oleh Holland dikategorikan ke dalam model personal style bertemakan sosial. Alih-alih subjek-subjek tersebut tampak lebih menyukai interaksi sosial, senang bergaul, memperhatikan masalah-masalah sosial, religius, berorientasi layanan masyarakat, dan tertarik pada kegiatan pendidikan (Tarsidi. D., 2007).

\section{d. Menikmati Kenyamanan, Rasa Nyaman Ketika Siswa Terbantu}

Menurut paparan narasumber: "Karena ketemu anak-anak yang kondisinya 'begitu' jadi tersentuh mas hehe...Butuh perhatian dan kasih sayang. Saya merasa nyaman aja kalo dekat dengan mereka." Subjek B merasa bahwa makna menjadi guru bimbingan dan konseling bagi dirinya adalah menikmati kenyamanan ketika bisa membantu siswa. Subjek B nyaman karena bisa membantu siswa yang bermasalah. Baginya, rasa nyaman itu membuatnya menjadi guru bimbingan konseling. Kenyamanan adalah salah satu aspek yang dapat meningkatkan kesejahteraan mental (well-being) dan akan berdampak pada efektivitas kinerja guru bimbingan dan konseling. Sebaliknya, stres kerja yang dialami guru BK akan berdampak kepada terhambatnya pekerjaan atau pemberian layanan yang akan dilakukan (Sandra, R., \& Ifdil, I., 2015). Dengan demikian, ihwal keefektifan kinerja konselor atau guru bimbingan dan konseling di sekolah maka seyogyanya dimulai dengan menghadirkan rasa nyaman dalam bekerja, dan menghindarkan diri dari hal-hal yang memicu stres.

\section{e. Menikmati Menjadi Orang Tua Bagi Siswa}

Narasumber C menuturkan: “Guru bimbingan konseling bukan sekedar jadi tempat konseling tapi bagaimana menjadi orang tua bagi mereka yang membutuhkan. Selama ini siswaku hampir sebagian besar dari keluarga 'broken home' dan kurang perhatian. Sistem bimbingan konseling di sekolahku yang 
akhirnya harus jadi ortu dalam arti sesungguhnya, ada yang jadi ayah dan aku jadi ibunya anak-anak. Itu menjadi sesuatu yang nyaman bagi saya.". Subjek C mencoba untuk menjelaskan kondisi sekolahnya dan kemudian menganggap bahwa dirinya merupakan ibu bagi siswa-siswa dalam arti yang sebenarnya. Karena banyak siswa yang kurang kasih sayang orang tua. Baginya, itu merupakan perlakuan yang membuat dia merasa nyaman. Adapun peran guru bimbingan konseling yang menjadikan siswa korban broken home tetap merasa nyaman untuk mengikuti layanan BK adalah guru BK diharapkan tampil sebagai informator, motivator, fasilitator, mediator, serta evaluator Hanik, U (2018). Tentunya peranan tersebut dibalut dengan emphatetic understanding yang tulus dari seorang konselor atau guru BK, yang demikian dapat menghampiri peranan seorang ibu yang penuh kasih sayang.

\section{f. Mendapat Pelajaran Hidup}

Narasumber D memaparkan: "Dari siswa itu saya justru banyak belajar, banyak hal yang bisa saya pelajari dari pengalaman, Misalnya.. mengatakan 'tidak' kepada anak. Kita sering melakukan berkali-kali dan hampir semua orang menganggap lumrah ketika kita ingin menolak sikap anak dengan kata 'tidak'. Tapi nyatanya 1 kata itu apabila penempatannya tidak tepat dampaknya cukup besar untuk anak kedepannya." Subjek D beranggapan bahwa menjadi guru bimbingan dan konseling merupakan upaya untuk belajar kembali. Dia justru belajar dari siswa-siswanya. Karena menurutnya, satu kata saja, atau respon yang jelek kepada siswa, maka akan berdampak pada siswa. Dari situ ia belajar untuk menggunakan kata yang sesuai pada penempatannya. Hal ini menunjukkan bahwa seorang konselor atau guru BK diharuskan memiliki keterampilan komunikasi konseling yang mumpuni, utamanya keterampilan mendengarkan keluhan konseli. Ihwal tersebut, Hariko, R. (2017) menyarankan bahwa penguasaan keterampilan komunikasi merupakan prasyarat mutlak bagi konselor untuk dapat menggunakan berbagai keterampilan konseling secara efektif dan efisien. 


\section{g. Sebagai Selingan, Batu Loncatan}

Menurut penuturan A: "Yang membuat saya bertahan sampai saat ini menjadi guru bimbingan konseling adalah, karena saya nunggu untuk pembukaan lowongan ASN lagi. Hehehe. Saya akan mencoba menjadi guru bimbingan dan konseling meskipun hanya menjadi tenaga honorer. Tapi tidak bisa terus menerus seperti ini. ketika saya sudah memiliki keluarga nanti, saya berusaha untuk mencari pekerjaan lain jika saya tidak menjadi ASN."

Pendapat subjek A tentang pekerjaannya rupanya kontradiksi dengan pendapat sebelumnya. Di sisi lain ia menganggap pekerjaan guru bimbingan dan konseling sebagai penggilan jiwa, tetapi di sisi lain ia menjadikan pengabdiannya itu sebagai jalan untuk menjadi ASN. Jika nanti dia sudah berkeluarga dan keadaan memungkinkan, maka ia lebih memilih mencari pekerjaan lain. Penggambaran vocational self-concept subjek A rupa-rupanya tergolong pada fase exploratory, dan memang umur subjek A masih berkisar 21-24 tahun (fresh graduate). Artinya, menurut Donald Super subjek A berada pada tahapan exploratory (usia 15-24) dalam perkembangan karir seseorang, ditandai dengan fase tentative (belum menentu) di mana kisaran pilihan dipersempit tetapi belum final (Tarsidi. D., 2007).

\section{h. Tidak mudah di PHK}

Sebagaimana paparan dari narasumber B bahwa: "Banyak pengalaman teman saya itu yang kerja di perusahaan beberapa tahun, tapi ujung-ujungnya di PHK. Yah aku gak mau kayak gitu lah. Tidak menjanjikan contohnya kena PHK. Banyak lembur. Aku lihat jadi guru juga banyak liburnya. Hehe..." Bagi subjek B, menjadi guru bimbingan konseling merupakan posisi aman. Dia tidak ingin bekerja di perusahaan swasta karena takut di PHK atau sampai bekerja lembur. Hal ini menunjukkan bahwa subjek B merasa bahwa menjadi guru bimbingan dan konseling merupakan profesi yang aman, jauh dari PHK ataupun bekerja lembur. 
Apalagi menurutnya, profesi guru itu banyak liburnya, kalau siswa libur, guru pun ikut libur, tergantung dari kondisi sekolah.

Dalam teori pembelajaran sosial kognitif yang digagas oleh Albert Bandura, maka perilaku ini merupakan hasil belajar yang diperoleh dari pengamatan lapangan yang kemudian terekam dalam kognisi seseorang yang berujung pada perilaku atribusi (mencontoh). Fenomena tersebut diistilahkan sebagai triadic reciprocality, artinya hubungan saling menyebabkan antara tiga faktor, yaitu: perilaku (B), faktor kognitif dan personal (P), dan pengaruh lingkungan (E), yang masing-masing beroperasi secara mandiri sebagai faktor penentu bagi faktorfaktor lainnya. Pengaruh-pengaruh tersebut bervariasi dalam kekuatannya dan tidak terjadi secara berbarengan (Tarsidi, D. 2010).

\section{Analisis Motivasi menjadi Guru BK}

Hasil penelitian menunjukkan 3 (tiga) tema utama makna menjadi guru bimbingan konseling. Pertama, sebagai panggilan jiwa; kedua, menikmati kenyamanan; dan ketiga, sebagai batu loncatan. Dari ketiga tema tersebut, kemudian membentuk subtema. Subtema dari panggilan jiwa; tidak berorientasi profit, mewujudkan masa depan siswa, dan keyakinan agama. Subtema dari menikmati kenyamanan; rasa nyaman ketika siswa terbantu, menikmati menjadi orang tua bagi siswa, dan mendapat pelajaran hidup. Subtema batu loncatan; menunggu jadi ASN dan tidak muda di PHK.

Hasil penelitian menunjukkan bahwa ada beberapa bagian dari statement subjek penelitian yang saling kontradiktif, misalnya menjadikan pekerjaan guru bimbingan dan konseling sebagai panggilan jiwa tapi disisi lain subjek penelitian menganggap bahwa ia menjadi guru bimbingan dan konseling karena dianggap sebagai profesi yang aman jika dibandingkan dengan pekerjaan lain misalnya di swasta, dengan akibat terjadi PHK.

Penelitian yang dilakukan oleh Kim dan Ling (2001) menyimpulkan bahwa peran pekerjaan menggambarkan banyak hal yang berkaitan dengan cara 
bekerja seseorang. Setiap dimensi dari peran pekerjaan mencakup aspek materi pekerjaan yang dapat mempengaruhi produktivitas kerja seseorang, semakin besarnya keragaman aktivitas pekerjaan yang dilakukan maka seseorang akan merasa pekerjaannya semakin berarti dan atau bermakna. Guru bimbingan konseling yang merasa bahwa pekerjaannya dinamis dan beragam, maka ia akan berusaha untuk meningkatkan produktivitasnya. Hal yang perlu diperhatikan tentu peran keberagaman bekerja dalam membentuk makna bekerja.

Pembentukan makna kerja juga dipengaruhi oleh ajaran agama, sebagaimana yang diungkapkan oleh Weber (1930). Weber menyoroti bahwa doktrin protestan berpengaruh terhadap etos kerja seorang Kristen. Doktrin tersebut menekankan bahwa kerja merupakan bagian dari ibadah dan panggilan untuk menata masyarakat. Makna kerja yang disebut oleh Weber merupakan panggilan suci dari tuhan. Sehingga menurut Weber, individu yang memiliki pemahaman agama yang kuat, akan berusaha untuk bekerja keras dalam menyelesaikan pekerjaannya.

Keller (2014) menyatakan bahwa pekerjaan merupakan rencana Tuhan yang Maha Esa dari semula dan merupakan anugerah bagi manusia. Sebelum kejatuhan, manusia diberikan mandat untuk mengusahakan bumi. Hal ini merupakan perintah yang jelas dari Tuhan yang Maha Esa agar manusia bekerja untuk menghasilkan sesuatu. Pekerjaan apapun, harus dilakukan dengan kesungguhan, demi kemuliaan Tuhan yang Maha Esa. Oleh karena itu, setiap manusia yang bekerja, harus terus meningkatkan kompetensinya agar mampu bekerja secara professional, namun tetap dalam iman dan harapan yang teguh kepada Tuhan yang Maha Esa.

Makna kerja sebagai panggilan jiwa merupakan satu keterkaitan dengan ajaran agama. Hal ini tentu berlandaskan pada keyakinan seseorang. Keyakinan terhadap ajaran agama yang kuat, memberikan interpretasi pada individu mengenai maknanya dalam melakukan suatu pekerjaan. 
Stuart A Schlegel (1997) tentang aspek pokok perilaku individu yaitu individu selalu bertindak sesuai dengan makna (yang dimiliki dan dialami) sehingga guru bimbingan dan konseling bekerja untuk menikmati kenyamanan yang mereka alami dari setiap layanan yang diberikan kepada konseli. Pemaknaan tersebut ada karena mereka melakukan interaksi dalam pekerjaan mereka. Mereka harus mengimplimentasikan makna tersebut dengan cara tetap bekerja sebagai guru bimbingan dan konseling yang dirasa memberikan kenyamanan dalam dirinya. Hal ini menunjukkan fakta bahwa data penelitian yang mengkategorisasikan makna kerja menjadi subtema rasa nyaman ketika membantu siswa, menikmati menjadi orang tua bagi siswa, dan mendapatkan pelajaran hidup, merupakan bukti bahwa guru bimbingan dan konseling melakukan interaksi dalam pemberian layanannya. Interaksi tersebut membentuk makna kerja yang diyakini oleh konselor.

Temuan penelitian selanjutnya adalah tema selingan, dengan subtema menunggu jadi ASN dan tidak mudah di PHK. Subjek penelitian menganggap bahwa profesi guru bimbingan dan konseling sebagai tenaga honorer, merupakan jalan cepat menuju ASN. Mereka berpendapat bahwa menjadi tenaga honorer, merupakan selingan untuk menunggu menjadi ASN. Selain itu, subjek penelitian juga menganggap bahwa menjadi guru bimbingan dan konseling merupakan posisi yang aman dibandingkan jika mereka bekerja sebagai karyawan swasta. Hal ini sejalan dengan pendapat Lakein (2007), bahwa waktu luang erat kaitannya dengan waktu apabila masuk dalam kategori discretionary time, yakni waktu yang digunakan menurut penilaian dan pilihan kita sendiri.

\section{Simpulan}

Pekerjaan merupakan bagian dari upaya untuk memenuhi kebutuhan, sekaligus sebagai penemuan makna kehidupan. Makna kerja setiap individu berbeda-beda, tergantung dari keyakinan dan kondisi dilingkungan kerjanya. Namun tidak bisa dipungkiri bahwa dalam satu profesi, individu membangun 
persepsi atas kebermaknaan pekerjaannya secara general. Jika kondisi lingkungan kerja nyaman, maka individu akan membangun makna kerja yang positif.

Pekerjaan sebagai guru bimbingan dan konseling memang tidak mudah. Pekerjaan yang melibatkan interaksi antar konseli ini menuntut keterampilan interpersonal konselor yang matang. Hasil penelitian menunjukkan bahwa guru bimbingan dan konseling memaknai pekerjaannya sebagai panggilan jiwa, menikmati kenyamanan, dan sebagai selingan. Tema pangggilan jiwa berupa guru bimbingan konseling yang tidak berorientasi profit, merupakan pekerjaan yang mulia karena berusaha untuk mewujudkan masa depan siswa, dan sebagai bagian dari keyakinan agama yang mereka pahami. Selanjutnya, guru bimbingan dan konseling memaknai pekerjaannya untuk menikmati kenyamanan dengan subtema merasa nyaman ketika membantu siswa, menikmati menjadi orang tua bagi siswa, dan mereka mendapatkan pelajaran hidup dari upaya bantuan yang dilakukan. Pemaknaan selanjutnya adalah sebagai selingan, dikarenakan mereka bekerja sebagai tenaga honorer yang merupakan batu loncatan untuk masa penantian menjadi ASN (Aparatur Sipil Negara), sekaligus membuat kondisi mereka menjadi aman karena ketakutannya di PHK jika bekerja sebagai karyawan di perusahaan swasta. Saran dari penelitian ini diharapkan menjadi rujukan dalam membantu guru bimbingan konseling dalam proses pemaknaan pekerjaannya melalui pengondisian lingkungan yang positif untuk meningkatkan produktivitas mereka dalam bekerja. 


\section{DAFTAR PUSTAKA}

Anshori \& Yuwono. (2012). Makna Kerja (Meaning of Work) Suatu Studi Etnografi Abdi Dalem Keraton Ngayogyakarta Hadiningrat Daerah Istimewa Yogyakarta. Media Jurnal Psikologi Industri dan Organisasi. 1, 3. Retrieved from http://journal.unair.ac.id/JPIO@makna-kerja-(meaning-of-work)-article$\underline{\text { 5616-media-50-category-10.html }}$

Calyptra: Jurnal Ilmiah Mahasiswa Universitas Surabaya Vol.2 No.1. Retrieved from https://media.neliti.com/media/publications/186050-ID-hubungan-antarakonflik-keluarga-kerja.pdf

Creswell, J. W. (1998). Penelitian Metode Kualitatif. Yogyakarta: Kencana Predana Media Group

Elliot, R., Fischer, C.T., \& Rennie, D.L. (1999). Evolving Guidelines for Publication of Qualitative Research Studies in Psychology and Related. British Journal of Clinical Psychology. 38, 215-229. Retrieved from http://psy.au.dk/fileadmin/site files/filer psykologi/dokumenter/Forskersk olen/Kurser09/Fishman/No 7Elliott Fischer Rennie 1999 Standards Qual Research.PDF

Hanik, U. 2018. Peran guru bimbingan konseling dalam mengatasi kenakalan siswa korban broken home di SMK Ma'arif NU 1 Wonolopo Kecamatan Mijen Kota Semarang: analisis fungsi bimbingan dan konseling Islam (Doctoral dissertation, UIN Walisongo Semarang).

Hariko, R. 2017. Landasan Filosofis Keterampilan Komunikasi Konseling. Jurnal Kajian Bimbingan dan Konseling, 2(2), 41-49.

Harpaz, I. 2002. Expressing a Wish to Continue or Stop Working as Related to The Meaning of Work. European Journal of Work and Organizational Psychology. (2), 177-198. Retrieved from https://www.researchgate.net/publication/228925998 Expressing a wish t o continue or stop working as related to the meaning of work

Irham, M. (2012). Etos Kerja Dalam Perspektif Islam. SUBSTANTIA, 14(1), 9-24.

Jati, W. R. (2018). Agama dan Spirit Ekonomi: Studi Etos Kerja dalam Komparasi Perbandingan Agama. Al Qalam, 35(2), 211-240.

Lakein, A. (2007). Manajemen Waktu. Jakarta: Mata Khatulistiwa

Luth, T. (2001). Antara perut \& etos kerja dalam perspektif Islam. Gema Insani.

Mappiare-AT, A. 2013. Tipe-Tipe Metode Riset Kualitatif: Untuk Eksplanasi Sosial Budaya dan Bimbingan Konseling. FIP Malang: Elang Mas Bersama Prodi BK

Maslow, A. (1954). Motivation and Personality. New York City : Harper \& Row Publishers Inc 
Morin, E. (2004). The meaning of work in modern times. Conference $10^{\text {th }}$ world congress on human resources manajement, IRRST. August, 20th, 2004 (pp. 112). Rio de janeiro, Brazil.

Nadjib, M. (2013). Agama, Etika dan Etos Kerja dalam Aktivitas Ekonomi Masyarakat Nelayan Jawa. Jurnal Ekonomi dan Pembangunan, 21(2), 137-150. Retrieved from https://media.neliti.com/media/publications/77547-IDagama-etika-dan-etos-kerja-dalam-aktivit.pdf

Puspita, M.D. (2012). Hubungan antara dukungan sosial dan makna kerja sebagai panggilan (calling) dengan keterikatan kerja. Calyptra : Jurnal Ilmiah mahasiswa Universitas Surabaya, 1 (1). Retrieved from http://download.portalgaruda.org/article.php?article=119109\&val=5455.

Rosso, B. D., Dekas, K. H., \& Wrzesniewski, A. (2010). On the Meaning of Work: A

Rusdiana, O., \& Affandi, M.A., (2013). Makna Kerja Bagi Buruh Petik Lombok Paradigma. 01,03), 1-5. Retrieved from http://jurnalmahasiswa.unesa.ac.id/index.php/paradigma/article/view/411 $\underline{9}$

Sandra, R., \& Ifdil, I. (2015). Konsep Stres Kerja Guru Bimbingan dan Konseling. Jurnal EDUCATIO: Jurnal Pendidikan Indonesia, 1(1), 80-85.

Smith, J. A. \& Osborn, M. (2009). Analisis Fenomenologi Interpretatif. Dalam J. A. Smith.(ed.). Psikologi Kualitatif: Panduan Praktis Metode Riset. (Edisi Terjemahan). Pustaka Pelajar: Yogyakarta.

Stuart, G, W. 2001. Principle and Practice of Pshychiatric Nursing, Edisi 7, Mosby, Philadelpia.

Tanudjaja, R.M. (2013). Hubungan Antara Konflik Keluarga-Kerja, Makna Kerja sebagai Panggilan, dan Persepsi Terhadap Dukungan Organisasional dengan Keterikatan Kerja pada Guru.

Tarsidi, D. 2007. Teori perkembangan karir. Jurnal Universitas Pendidikan Indonesia.

Tarsidi, D. 2010. Teori Kognitif Sosial Albert Bandura. Universitas Pendidikan Indonesia. Bandung.

Thaib, E. J. 2014. Al-Qur'an dan As-Sunnah Sebagai Sumber Inspirasi Etos Kerja Islami. Jurnal Dakwah Tabligh, 15(1), 1-9.

Theoretical Integration and Review. Research in Organizational Behavior, 30, 91127. Retrieved from https://www.sciencedirect.com/science/article/pii/S0191308510000067

Weber, M. 1987. The Protestant Ethics and the Spirit of Capitalism. Sydney: Alllen \& Unwin.. 
Motivasi Menjadi Guru Bimbingan dan Konseling (Studi Fenomenologi terhadap......

Weber, M. 2006. Etika Protestan dan Spirit Kapitalisme (terjemahan). Yogyakarta: Pustaka Pelajar. 